\title{
PERAN YAYASAN TENDAVISI INDONESIA DALAM MENGATASI KRISIS AIR MELALUI PROGRAM WAKAF SUMUR DI KAMPUNG SITUSIPATAHUNAN DESA BALEENDAH
}

\author{
Riana Damayanti Fauziah \\ Program Studi Pendidikan Masyarakat IKIP Siliwangi, Cimahi - Jawa Barat - Indonesia \\ rianadamayantif@gmail.com
}

Received: April, 2021; Accepted: Mei, 2021

\begin{abstract}
The background of the research is about phenomenon of situsipatahunan village. People around the situsipatahunan are continuining to suffer from acces poor to water and hygiene. The purpose of research is : (1) To find out the process of well waqf program. (2) To find out the relationship between the well waqf program with the community empowerment process. The type of research is descriptive field research by using qualitative approach. Then the techniques to collect data in research uses interview, observation, and documentation. The research location is in the kampung situsipatahunan rt/rt 03/05 desa Baleendah, kec. Baleendah - kab. Bandung and the subject research are the management of the foundation as a responsible person of well waqf program and the communities who resceive the benefits off well waqf as many as fourty families around the construction of well waqf. Based on the result the activity of well waqf program goes well. The program is carried out by means of sites surveys activities, fundraising and the well waqf execution. The relationship between well waqf and community empowerment is the use off well waqf to increase the economic level of people in Situsipatahunan village.
\end{abstract}

Keywords: Water Crisis, Community Empowerment, Well Waqf

\begin{abstract}
Abstrak
Penelitian ini dilatarbelakangi dengan adanya permasalahan yang ditemukan yaitu kondisi Kampung Situsipatahunan yang kekurangan sumber air bersih atau disebut kiris air. Tujuan penelitian ini yaitu (1) untuk mengetahui pembangunan program wakaf sumur. (2) Untuk mengetahui keterkaitan wakaf sumur dengan proses pemberdayaan masyarakat di kampung Situsipatahunan. Metode yang digunakan yaitu pendekatan kualitatif dengan metode deskriptif. Teknik dalam pengumpulan data yaitu pendekatan kualitatif dengan metode deskriptif. Teknik pengumpulan data dalam penelitian ini menggunakan teknik wawancara, observasi, dan dokumentasi. Lokasi penelitian di kampung Situsipatahunan Rt 03 Rw 05 Desa Baleendah Kecamatan Baleendah Kabupaten Bandung dan yang menjadi subjek penelitian adalah dari pengelola yayasan sebagai penanggung jawab program wakaf sumur sebanyak 2 orang dan masyarakat penerima manfaat wakaf sumur sebanyak 40 Kepala Keluarga sekitar pembangunan wakaf sumur. Hasil penelitian menunjukan bahwa kegiatan program wakaf sumur berjalan dengan baik. Kegiatan program ini dilakukan dengan cara survey tempat, penggalangan dana dan pengerjaan pembangunan sumur. Keterkaitan wakaf sumur dengan pemberdayaan masyarakat adanya kebermanfaatan wakaf sumur terhadap peningkatan taraf ekonomi warga kampung Situsipatahunan.
\end{abstract}

Kata Kunci : Krisis Air, Pemberdayaan Masyarakat, Wakaf Sumur

How to Cite: Fauziah, R.D. (2021). Peran Yayasan Tenda Visi Indonesia dalam Mengatasi Krisis Air Melalui Program Wakaf Sumur di Kampung Situsipatahunan, Desa Baleendah. Comm-Edu (Community Education Journal), 4(2), 69-75. 
70 Fauziah, R.D. Peran Yayasan Tenda Visi Indonesia dalam Mengatasi Krisis Air Melalui

Program Wakaf Sumur di Kampung Situsipatahunan, Desa Baleendah

\section{PENDAHULUAN}

Pentingnya air bagi keberlangsungan makhluk hidup sudah tidak dapat dilepaskan dalam kehidupan sehari-hari. Mengingat air adalah salah satu kebutuhan pokok yang digunakan oleh setiap makhluk hidup di muka bumi. Sebagian besar pembentuk tubuh dari manusia adalah 73\% terdiri dari air. Oleh karena itu pentingnya menjaga kestabilan dan kebersihan air dengan menjaga kelestarian alam seperti tidak membuang sampah sembarangan, tidak membuang limbah ke sungai atau ke sumber mata air karena akan mempengaruhi kualitas air yang ada di muka bumi.

Dalam pengelolaan sumber air membutuhkan perhatian yang cukup serius sehingga manusia tidak lagi mengalami krisis air. Permasalahan pengelolaan air telah menjadi isu internasional, tidak terkecuali dalam pandangan Islam. Pada tahun 1998, Research Centre (IDRC) mengadakan lokakarya tentang pengelolaan sumber daya air di negara-negara Islam. Dalam lokakarya ini, ditemukan bahwa Islam menentukan prioritas utama kepada siapa yang paling berhak air tersebut dialokasikan. Prioritas pertama adalah untuk memenuhi kepuasan dahaga manusia. Kedua untuk memenuhi kebutuhan ternak, dan yang ketiga adalah untuk mengairi tanaman. Kemudian lingkungan juga memiliki hak air yang kuat dan spesifik. Dalam Islam menyatakan bahwa semua makhluk hidup di muka bumi berhak atas jumlah dan kualitas air yang cukup untuk kebutuhan mereka. Selain itu, hukum Islam menetapkan hukuman bagi mereka yang membuat kerugian, dan memberikan sanksi terhadap orang yang melakukan pencemaran air (Fakhrina, 2013).

Di Indonesia terdapat beberapa wilayah yang mengalami krisis air atau kekurangan sumber air bersih sehingga tidak dapat memenuhi kebutuhan air dalam kehidupan sehari-hari. Salah satunya terjadi di daerah Kabupaten Bandung Barat menurut Badan Penanggulangan Bencana Daerah (BPBD) Kabupaten Bandung Barat (KBB) mencatat 32.087 Kepala Keluarga di 49 Desa dari 10 Kecamatan yang ada di KBB menjerit kekurangan air bersih. Berdasarkan data 10 kecamatan itu ialah, Kecamatan Cipatat (6), Sindangkerta (2), Cipongkor (4), Parongpong (6), Cihampelas (10), Ngamprah (2), Padalarang (2), Cipeundeuy (12), Cisarua (3), dan terakhir Kecamatan Batujajar yang mengalami kekeringan terjadi di 3 desa. Untuk mencukupi kebutuhan air sebanyak $32.087 \mathrm{KK}$ di 49 desa tersebut dibutuhkan pasokan air bersih sekitar 14.439.150 liter (Januri, 2019). Kekurangan air bersih atau krisis air tersebut sama halnya dengan yang terjadi di Kampung Situsipatahunan Rt 03 Rw 05 Desa Baleendah Kecamatan Baleendah Kabupaten Bandung.

Dalam UU No. 41 dijelaskan tentang wakaf yaitu sebagai sebuah payung hukum yang kuat dan berskala nasional. Undang - Undang tersebut mendefiniskan bahwa "Wakaf adalah perbuatan hukum wakif untuk memisahkan dan/atau menyerahkan sebagian harta benda miliknya untuk dimanfaatkan selamanya atau untuk jangka waktu tertentu sesuai dengan kepentingannya guna keperluan ibadah dan/atau kesejahteraan umum menurut syariah" 23 UU No. 41 Tahun 2004 tentang Wakaf pasal 1 ayat (1).

Wakaf di Indonesia masih sangat berpotensial karena Indonesia merupakan negara yang sebagian besar mayoritas penduduknya adalah umat muslim dan menjadi pemeluk agama Islam terbesar di dunia. Kesadaran masyarakat Indonesia yang memeluk agama Islam mengenai pentingnya berwakaf sudah cukup tinggi . Karena tanpa adanya kesadaran yang dimiliki oleh masyarakat Indonesia maka potensi wakaf tidak akan dapat tergali. Selain itu memiliki kemampuan pengelolaan yang baik tentang wakaf maupun penyaluran yang tepat sasaran sangat dibutuhkan (Purwaningsih, 2020). 
Konsep pemberdayaan (empowerment) adalah salah satu upaya untuk memberikan otonomi, wewenang, dan kepercayaan kepada setiap individu dalam suatu organisasi, dan mendorong mereka untuk lebih kreatif agar dapat menyelesaikan tugasnya dengan baik. Kemudian dengan begitu dapat meningkatkan kemandirian dan kualitas sumber daya manusia (Hadi, 2010).

Peran lembaga masyarakat dalam mengatasi permasalahan tersebut sangat berperan penting. Oleh karena itu Yayasan Tenda Visi Indonesia ikut berperan aktif dalam mengatasi permasalahan yang terjadi yaitu membuat program wakaf sumur.Wakaf sumur merupakan program yang dikembangkan oleh Yayasan Tenda Visi Indonesia. Program ini bertujuan untuk membantu warga sekitar dalam mendapatkan air bersih. Masalah krisis air di daerah Situsipatahunan sangat mengganggu aktivitas warga. Maka Yayasan Tenda Visi membuat program wakaf sumur untuk mengatasi permasalahan tersebut.

Berdasarkan uraian di atas, dapat dirumuskan permasalahan yang terjadi adalah krisis air karena kurangnya sumber daya air atau biasa yang disebut sumur di kampung Situsipatahunan. Sehingga perlu di bangun sumber air yang bisa digunakan warga sekitar untuk memenuhi kebutuhan sehari-hari melalui program wakaf.

Dengan demikian, dalam penelitian ini penulis bermaksud mendeskripsikan program wakaf sumur untuk mengatasi krisis yang dilaksanakan oleh Yayasan Tenda Visi Indonesia di kampung Situsipatahunan Rt 03 Rw 05 Desa Baleendah Kecamatan Baleendah Kabupaten Bandung.

\section{LANDASAN TEORI \\ Wakaf}

Konsep wakaf yaitu memberikan harta yang sangat dicintai kepada penerima manfaat secara cuma-cuma untuk kesejahteraan masyarakat. Orang yang berwakaf atau disebut wakif dituntut memiliki rasa ikhlas yang cukup tinggi ketika mewakafkan sebagian hartanya demi kesejahteraan dan kebermanfaat masyarakat banyak karena keluasan ekonomi yang dimiliki merupakan sebuah karunia dan nikmat yang diberikan Allah Subhanahu Wata'ala.

Wakaf merupakan bagian dari program sedekah yang menghasilkan manfaat secara berkelanjutan (sustainable). Melalui wakaf sumber-sumber ekonomi tidak hanya terfokus kepada orang-orang kaya, akan tetapi juga memungkinkan tersampaikan kepada sebagian masyarakat yang sangat membutuhkan. Besarnya potensi dan luasnya pemanfaatan wakaf tunai menjadi salah satu solusi yang dapat digunakan untuk proses pemberdayaan ekonomi umat (Yusali, 2019).

Wakaf dibedakan menjadi dua jenis, yaitu wakaf produktif dan wakaf konsumtif (Non Produktif). Wakaf konsumtif atau non produktif adalah harta benda wakaf yang digunakan secara langsung untuk keperluan atau kepentingan umat. Di Indonesia saat ini bahwa wakaf konsumtif (non produktif) di gunakan untuk masjid, sekolah, tempat pemakaman. Jika dilihat dari sisi sosial, hal ini cukup efektif, tetapi dampaknya ialah akan berpengaruh pada segi ekonomi di masyarakat. Sehingga perlu adanya kesinambungan dengan wakaf yang dikelola secara produktif agar tingkat kesejahteraan masyarakat dapat terealisasikan secara maksimal (Anas \& Ryandono, 2017). 
72 Fauziah, R.D. Peran Yayasan Tenda Visi Indonesia dalam Mengatasi Krisis Air Melalui

Program Wakaf Sumur di Kampung Situsipatahunan, Desa Baleendah

\section{Pemberdayaan Masyarakat}

Pemberdayaan dapat diartikan sebagai upaya memenuhi kebutuhan yang di inginkan oleh individu, kelompok dan masyarakat luas agar mereka memiliki kemampuan untuk melakukan pilihan dan mengontrol lingkungannya agar dapat memenuhi keinginan - keinginannya termasuk aksebilitasnya terhadap sumber daya yang terkait dengan pekerjaannya, aktivitas sosial dan lain-lain (Mardikanto \& Soebiato, 2017).

Dalam pemberdayaan masyarakat melalui program wakaf sumur tentu ada target yang dijadikan sebagai penerima manfaat atau kelompok sasaran. Ada beberapa pengertian tentang penerima manfaat yang telah mengganti istilah "sasaran penyuluhan" menjadi penerima manfaat (benificiariest).

Dalam pengertian "penerima manfaat" seperti yang dikemukakan (Mardikanto \& Soebiato, 2017) tersebut, terkandung makna bahwa :

1. Berbeda dengan kedudukannya sebagai "sasaran", masyarakat sebagai penerima manfaat memiliki kedudukan yang setara dengan penentu kebijakan, fasilitator dan pemangku kepentingan yang lain.

2. Penerima manfaat bukanlah objek atau "sasaran tembak" yang layak di pandang rendah oleh penentu kebijakan dan para fasilitator, melainkan ditempatkan pada posisi terhormat yang perlu dilayani atau difasilitasi sebagai rekan sekerja dalam mensukseskan pembangunan.

3. Berbeda dengan kedudukannya sebagai "sasaran" yang tidak punya pilihan atau kemampuan untuk menawar setiap materi yang disampaikan, selain harus menerima dan mengikutinya, penerima manfaat memiliki posisi tawar yang harus dihargai untuk menerima atau menolak inovasi yang di sampaikan fasilitatornya.

4. Penerima manfaat tidak berada dalam posisi di bawah penetu kebijakan dan para fasilitator, melainkan dalam kedudukan setara dan bahkan sering justru lebih tinggi kedudukannya, dalam arti memiliki kebebasan untuk mengikuti ataupun menolak inovasi yang disampaikan oleh penyuluhnya

5. Proses belajar yang berlangsung antara penyuluh dan penerima manfaat bukanlah bersifat vertical (penyuluh menggurui penerima manfaatnya), melainkan proses belajar bersama yang parsitipatif.

\section{METODE PENELITIAN}

Dalam penelitian ini menggunakan pendekatan penelitian kualitatif. Pendekatan tersebut digunakan karena ada beberapa ciri yaitu meneliti kondisi obyek yang alamiyah. Menurut (Sugiyono, 2017) penelitian kualitatif adalah metode penelitian yang berlandaskan pada filsafat postpositivisme, digunakan pada kondisi untuk meneliti pada kondisi obyek yang alamiyah, (sebagai lawannya adalah eksperimen) dimana peneliti adalah sebagai instrument kunci, teknik pengumpulan data dilakukan secara triangulasi (gabungan), analisis data bersifat induktif/kualitatif dan hasil penelitian kualitatif lebih menekankan makna dari pada generalisasi. Dalam penelitian ini metode yang digunakan adalah metode deskriptif. Alasan menggunakan pendekatan kualitatif deskriptif karena permasalahan yang di bahas tidak berhubungan dengan angka-angka. Tetapi menyangkut pendeskripsian, penguraian dan penggambaran suatu masalah yang sedang terjadi. Adapun teknik pengumpulan data yang digunakan oleh penulis adalah metode observasi, wawancara, dan dokumentasi. Peneliti juga menggunakan pedoman wawancara dalam proses mendapatkan informasi untuk tujuan penelitian. 
Penelitian ini di laksanakan di Kampung Situsipatahunan Rt 03 Rw 05 Desa Baleendah Kecamatan Baleendah Kabupaten Bandung. Subjek yang di pilih dalam penelitian ini adalah pengelola yayasan sebagai penanggung jawab program wakaf sumur sebanyak 2 orang dan warga penerima manfaat wakaf sumur sebanyak 40 kepala keluarga.

Adapun teknik analisis data yang digunakan dalam penelitian ini meliputi : (1) Reduksi Data; (2) Display Data dan ; (3) Penarikan Kesimpulan.

\section{HASIL DAN PEMBAHASAN}

\section{Hasil}

\section{Pembangunan Wakaf Sumur}

Wakaf Sumur adalah salah satu program sosial yang dikembangkan dan dilaksanakan oleh Yayasan Tenda Visi Indonesia. Program ini bertujuan untuk membantu masyarakat dalam mendapatkan air bersih. Adapun proses yang dilakukan dalam pembangunan wakaf sumur adalah sebagai berikut:

a. Survey tempat

Yayasan Tenda Visi Indonesia melakukan survey tempat untuk rencana pembangunan wakaf sumur apakah sesuai atau tidak dengan karakeristik penerima manafaat. Kemudian terpilih Kampung Situsipatahunan Rt 03 Rw 05 Desa Balendah Kecamatan Baleendah Kabupaten Bandung dengan jumlah 80 kepala keluarga dan kurang lebih sekitar 40 kepala keluarga sebagai penerima manfaat wakaf sumur.

\section{b. Pengumpulan dana}

Pengumpulan dan dilakukan dengan cara "fundrising" dan dana yang dihasilkan berasal dari donatur tetap maupun donatur tidak tetap Yayasan Tenda Visi Indonesia. Fundrising merupakan kegiatan dalam rangka mengumpulkan dana dari masyarkat ( baik individu, kelompok, organisasi dan pemerintah) ysng digunakan untuk membiayai program dan kegiatan operasional lainnya untuk mencapai suatu tujuan program lembaga/organisasi. Dana yang diperlukan dalam pembangunan wakaf sumur yaitu sebesar 25.0000 .0000 dan tim fundrising berhasil mengumpulkan dana tersebut dalam kurun waktu selama 14 hari.

\section{c. Pengerjaan pembangunan sumur}

Pengerjaan pembangunan sumur memerlukan waktu selama 10 hari dan di bantu oleh warga sekitar kampung Situsipatahunan. Manfaat yang di hasilkan dalam pembuatan wakaf sumur yaitu masyarakat mendapatkan kemudahan untuk mencukupi kebutuhan air bersih dalam kehidupan sehari-hari.

\section{Keterakaitan wakaf sumur dengan pemberdayaan masyarakat}

Berdasarkan hasil wawancara dengan salah satu penerima manfaat dari program wakaf sumur, krisis air yang terjadi di kampung Situsipatahunan cukup meyulitkan warga dalam memenuhi kebutuhan air sehari-hari. Dengan adanya program wakaf sumur dapat membantu warga salah satunya dengan meningkatkan taraf ekonomi masyarakat. Hal ini bisa dilihat dari beberapa warga yang membuka usaha menggunakan air dari program wakaf sumur.

Hal ini dibuktikan dengan adanya beberapa warga dari 40 kepala keluarga penerima manfaat yang menggunakan wakaf air sumur untuk mengolah produk jualannya, seperti berjualan bakso, makanan khas sunda (seblak), jus dan produk usaha lainnya. Sehingga adanya keterkaitan antara pemberdayaan masyarakat baik dari segi ekonomi maupun pemenuhan 
kebutuhan warga sekitar melalui wakaf sumur. Hal ini seiring dengan tujuan utama program tersebut yaitu terpenuhi nya kebutuhan air bersih warga sekitar kampung Situsipatahunan. Sehingga warga bisa lebih produktif dalam menghasilkan sebuah usaha untuk meningkatkan taraf ekonomi melalui wakaf sumur tersebut.

Seperti yang diutarakan oleh salah satu pengelola dari Yayasan Tenda Visi Indonesia sebagai penanggung jawab program wakaf sumur bahwa sebagian besar bekerja sebagai buruh harian lepas. Sehingga terdapat beberapa warga yang cukup kesulitan dalam menyediakan sumber air bersih. Sebelum adanya wakaf sumur banyak warga mengambil air bersih ke sumber air yang terletak di dekat situ dengan cara bergantian karena mereka harus berbagi dengan warga lainnya. Warga sekitar mengambil air menggunakan dirigen-dirigen dan di angkut menggunakan roda karena posisi sumber air cukup jauh dari tempat tinggal warga yaitu tepat berada di bawah pemukiman. Melihat kondisi tersebut Yayasan Tenda Visi Indonesia mencoba mengatasi permasalahan yang terjadi yaitu dengan cara mengadakan program wakaf sumur.

\section{Pembahasan}

Dalam proses pemberdayaan masyarakat terdapat berbagai cara yang bisa dilakukan salah satunya melalui program wakaf sumur. Pengelolaan wakaf sumur masih terbilang jarang di Indonesia padahal sudah di contohkan oleh salah satu sahabat Rosulullah Shallau'alaihi wasallam yaitu Utsman bin Affan RA yang telah dikenal dengan kerdermawanannya yaitu mewakafkan sumur. Wakaf sumur tersebut dipakai untuk masyarakat Madinah yang saat itu mengalami kesulitan air. Namun saat ini beberapa lembaga atau yayasan sudah mulai mengembangkan wakaf sumur, salah satunya yang dilaksanakan oleh Yayasan Tenda Visi Indonesia. Wakaf terbagi kedalam dua jenis yaitu wakaf produktif dan wakaf konsumtif (non produktif).

Pembangunan sumur di Kampung Situsipatahuan termasuk ke dalam wakaf sumur produktif karena selain menghasilkan kemudahan bagi warga dalam memenuhi kebutuhan air bersih juga memudahkan warga untuk melakukan usahanya. Wakaf ini berarti mendatangkan aspek ekonomi dan kesejahteraan masyarakat. Secara terminologi wakaf produktif adalah perubahan dari pengelolaan wakaf yang profesional untuk meningkatkan atau menambah manfaat wakaf. Sedangkan Muhammad Syafi'i Antonio mengatakan bahwa wakaf produktif adalah pemberdayaan wakaf yang ditandai dengan ciri utama, yaitu pola manajemen wakaf harus terintegrasi, asas kesejahteraan nazir, asas transformasi dan tanggungjawab (Munir, 2015).

Sebagaimana telah dikemukakan oleh (Mardikanto \& Soebiato, 2017) bahwa dalam proses pemberdayaan masyarakat terdapat aspek yang harus dipenuhi yaitu salah satunya adanya "sasaran penyuluhan" atau yang telah di ganti menjadi penerima manfaat. Dalam hal ini warga sebagai penerima manfaat dari program wakaf sumur mendapatkan kemudahan dalam memenuhi kebutuhan sehari-hari. Penerima manfaat mengalami peningkatan taraf ekonomi dan kesejahteraan. Hal ini bisa dilihat dari berbagai usaha yang dilakukan oleh warga sekitar Kampung Situsipatahunan. Seperti yang telah dinyatakan oleh Chamber pemberdayaan masyarakat adalah konsep pembanguan ekonomi yang merangkum nilai-nilai masyarakat untuk membangun paradigma baru dalam pembangunan yang bersifat people-centered, participatory, empowerment and sustainable. Lebih jauh Chamber menjelaskan bahwa konsep pembangunan dengan model pemberdayaan masyarakat tidak hanya semata-mata 
memenuhi kebutuhan dasar (basic need) masyarakat tetapi lebih sebagai upaya mencari alternatif pertumbuhan ekonomi lokal (Noor, 2011).

Dalam pelaksanaan pembuatan wakaf sumur juga mengalami beberapa rintangan yaitu dana yang diperlukan cukup besar. Selain itu hambatan juga datang dari proses pembangunan sumur yang dihadapkan dengan kondisi struktur tanah cukup keras dan masih terdapat batubatu besar. Sehingga para pekerja beserta warga sekitar harus lebih sabar dan berhati-hati dalam penggalian atau pengeboran sumur.

\section{KESIMPULAN}

Krisis air merupakan permasalahan yang sering terjadi di Indonesia, hal tersebut bisa disebabkan karena kurangnya sumber air ataupun kondisi cuaca yang terjadi di Indonesia. Salah satu upaya untuk mengatasi permasalahan tersebut adalah dengan diadakannya program wakaf sumur. Wakaf sumur adalah salah satu program sosial yang dilaksanakan Yayasan Tenda Visi Indonesia untuk mengatasi krisis air di kampung Situsipatahunan. Pembangunan wakaf sumur dilakukan dengan beberapa tahap, yaitu: (1) survey tempat, (2) pengumpulan dana, (3) pengerjaan pembangunan sumur. Wakaf sumur termasuk ke dalam wakaf produktif karena dapat digunakan masyarakat dalam membuka usaha dan memenuhi kebutuhan hidup sehari-hari. Keterkaitan antara wakaf sumur dengan pemberdayaan masyarakat salah satunya yaitu dapat meningkatkan taraf ekonomi dan kesejahteraan bagi warga kampung Situsiapathunan sebagai penerima manfaat wakaf sumur. Adapun faktor penghambat dalam proses pembangunan wakaf sumur adalah selain biaya yang diperlukan cukup besar juga kondisi struktur tanah yang masih terdapat batu-batu besar sehingga cukup menyulitkan dalam proses pengeboran sumur.

\section{DAFTAR PUSTAKA}

Anas, A., \& Ryandono, M. N. (2017). Wakaf produktif dalam pemberantasan kemiskinan melalui pemberdayaan ekonomi di Yasyasan Nurul Hayat Surabaya. Jurnal Ekonomi Syariah Teori dan Terapan, 4(3), 253.

Fakhrina, A. (2013). Pengelolaan Sumber Daya Air Di Dukuh Kaliurang: Perspektif Ekonomi Islam. Jurnal Penelitian, 9(1).

Hadi, A. P. (2010). Konsep Pemberdayaan, partisipasi dan kelembagaan dalam pembangunan "Yayasan Agribisnis/Pusat Pengembangan Masyarakat Agikarya (PPMA).

Januri, T. (2019, September Rabu). Krisis Air Bersih Melanda 32.087 KK di KBB. Retrieved November Selasa, 2020, from Ayobandung.com: https://ayobandung.com/read/2019/09/11/63377/krisis-air-bersih-melanda-32087-kk-di$\mathrm{kbb}$

Mardikanto, T., \& Soebiato, P. (2017). PEMBERDAYAAN MASYARAKAT DALAM PERSPEKTIF KEBIJAKAN PUBLIK. Bandung: Alfabeta.

Munir, A. S. (2015, September). Optimalisasi Pemberdayaan Wakaf Secara Produktif. Ummul Qura, 6(2).

Noor, M. (2011, Juli). Pemberdayaan Masyarakat. CIVIS, 1(2).

Purwaningsih, S. D. (2020). PERAN WAKAF DALAM MENINGKATKATKAN PEMBERDAYAAN EKONOMI UMAT. Jurnal Ekonomi, Bisnis dan Akuntansi, 22(2), 191-203.

Sugiyono. (2017). Metode Penelitian Kuantitatif, Kualitatif dan R\&D. Bandung: Alfabeta.

Yusali, S. (2019, Februari). Model Pengelolaan Wakaf Tunai (Waqf Al Nuqud) Sebagai Sarana Pemberdayaan Umat (Studi Kasus Pada Global wakaf ACT Malang. Jurnal Ilmiah Mahasiswa, 7(2). 